\section{B A Institute of \\ YK Business Administration \\ 六下 \\ Karachi \\ Leadership and Ideas for Tomorrow}

Business Review

Volume 9 Issue 1 January-June 2014

$1-1-2014$

\title{
Book Review of: The African genius: An introduction to African cultural and social history, Basil Davidson
}

Tufail A. Qureshi

Institute of Business Administration, Karachi

Follow this and additional works at: https://ir.iba.edu.pk/businessreview

Part of the Africana Studies Commons, and the Social and Cultural Anthropology Commons

\section{(c) (1)}

This work is licensed under a Creative Commons Attribution 4.0 International License.

\section{Recommended Citation}

Qureshi, T. A. (2014). Book Review of: The African genius: An introduction to African cultural and social history, Basil Davidson. Business Review, 9(1), 119-130. Retrieved from https://doi.org/10.54784/ 1990-6587.1233 


\title{
BOOK REVIEW
}

\section{The African Genius : An Introduction to African Cultural and Social History, Basil Davidson}

\author{
(An Atlantic Monthly Press Book, Brown and Company, 1969, pp. 367).
}

This book consists of essays which fall into two groups, concerned respectively with the cultural and social history of the African peoples. The two themes are neatly connected, however, in that the study of African Genius can be seen to correct many a historical misconceptions and distortions. Unlike most historical accounts, Davidson approaches the African world as the African world-view as a lived-world, the Lebenswelt, in the manner suggested by the contemporary philosophical approaches to history.

Part one of the book is devoted to a study of African World where Davidson critically examines the colonial vision of African humanity that arose essentially from the categories of "race" and "class" (26).* The colonial vision portrayed African societies as "without history" and African life as a "perpetual vacuum of experience". Colonial writers, such as Burton, attributed the arrested development of African to some "fatal deficiency of their nature", such as "diminished frontal lobes" , "insufficiently reliable supragranular layer of cortex", and "their brains being too small for civilized development". Davidson rejects all such notions as Just Plain Nonsense (23-28). In contrast to such culturally biased notions of the Victorian man, Davidson offers a diachronical study of African societies based on universal assumptions of logic and morality. He contends that although "the forms have been different ... but not the principles of intelligence and apprehension, not the essential content”(27). He argues that The Formative Origins (28-32) of the African civilization lie in the peculiar mood and temper of the African people and their optimism which comes from the living on a frontier, on the edge of 'somewhere else', on the verge of 'something different', "where anything may be possible as long as human courage and endeavor are prepared to make it so" (30-31).

He reinforces his arguments by setting his observations against The Physical Problems (32-36), i.e., the ecological problems of African environment where the physical confronts the spiritual in an idiom perfectly at one with the African World-view.

Unlike the historians and philosophers who have celebrated the Greeks for overcoming the utter lack of precede "Davidson attributes the epithet to the originality of the African mind and spirit (37). Isolated by the desiccation of the Sahara around 2000 B.C., the African Genius is reflected in the creative legends of the Dinka, the Akran, the Mosi and the cattle folks in Uganda and Zululand, for and Dogon, all of whom celebrated the cosmological symbolism of dialectical principle of Unity and Variation (36-41). A striking parallel exists in the early Greek philosophy. The principle of Unity and Variation, as conceived by the Africans, deals with the "conception of the universe that is based, on the one hand, on a principle of variation of matter and, on the other, on a general movement of the universe as a whole". Thales, Anaximander, Anaximenes , Pythagoras, Heraclitus, Empedocles and Anaxagoras, one would recall, were the Greek philosophers to have dealt with the problem of substance and change. The Africans believed principles that the opposite principle support each other in an equilibrium which the individual conserves in his being. 
Davidson takes issues with Dean Farrar who described the features of the Africans as "invariable and expressionless", marked by the "dead and blank uniformity" of their mind. The Africans, said Farrar, have never "originated a single discovery"; they have never "promulgated a single thought", "established a single institution" or "hit upon a single invention". Sir Charles Eloit described the mind of the East Africans as tabula rasa. Hence the colonial paternalism, raised to the position of dominion. In the affiliation and continuity of the African, demonstrating the tabula piena of their ancestral knowledge, with an accent on the social and political wisdom of the past.

Davidson argues that the Africans conceived their social needs in religious terms and envisioned their religious needs lying at the heart of social evolution. Thus the social fabric of the African experience derives its dynamics from Balance with Nature (54-67) the elan vital which runs through the ancestrally chartered system offers spiritual legitimation, sanctioned law and order, psychological security and personal identification. A man outside his clan, according to the Kongo, is "a grasshopper which has lost its wings", reflecting , politically, the tension and relief, anxiety and security of the tribal situation. Thus, economically and in its jural and moral assumptions, "extended family" constitutes the antithesis of the "free enterprise individualism". According to the Tallensi of northern Ghana, the individual has the rights by virtue of the obligations he fulfills to the community. Therein lies the ideal pattern of social and political growth. The pattern demands that no matter how empirical in nature, innovations lose their socio-political significance if or when they cannot be absorbed and drawn into the ancestral system. In the Dinka material culture, nothing which outlasts a single life-time is of any importance. In contrast to the modern acquisitive predilection, the Pondo and the Dinka detested the pushing egotism and the desire for personal wealth and power for it imperils the precarious balance with nature. In addition to the ecological factors, such as the logic behind the practice of "shifting cultivation" or, as it is contemptuously called , "slash and burn". Enough is enough, according to Bemba ethos. "To find one beehive is good luck, to find two is very good luck, to find three is witchcraft". Such egalitarian conceptions and norms constituted the fabric of the Moral Order (67-80) of the materially simple and technologically backward African societies which were marked culturally by a highly developed awareness of the limits of the Possible.

The principle of limitation by alternatives permeates the African consciousness and generates an inner tension which finds its creative expression in a controlled freedom visible in African dancing and experiments in sculptural form.

Placed within the hierarchical structure of the African traditional political culture, these polarities reflect the tension between lineage loyalty and the welfare of the community. The roots of the history of Chiefs (as among the Amba and the Nuer ) lie in that. Implicitly, it touches upon the power structure of the traditionally stratified polity, subsumed under the domain of moral order. The Lozi of Western Zambia, like the Tallensi, conceptualized power in terms of the structural equilibrium, in which the rights and duties are harmoniously sustained. When the equilibrium, demanded by the Spirit of the Earth, is disturbed, ancestors turn away and chaos reigns the earth. Thus the Earth-priests, the Zande cult of ancestors and the sub-cultural behaviour patterns of the Konkomba, based on the ancestral wisdom, celebrate the harmony between the knowledge of facts and attitudes, between behavioural and affective goals. Davidson distinguishes between Societies with Government and Societies without Government(80-91) and contrasts the aristocratic societies of the Wolof of Senegal and the Yoruba of Nigeria with the egalitarian systems of the Tallensi and Konkomba. 
In the Age-set Training (80-106), the author offers instructive educational examples of the manner in which power was assumed and realized at the successive development stages through cultivation of socio-culturally approved patterns of behavior based on moral assumptions. The salient characteristic of such training, hierarchical and quasi-political in nature, is reflected in the degree of socio-cultural stratifications well developed among the Daudi Lmbadu of the Tirki, Kipsigi and Nandi of Kenya, the Bantu of South Africa and the Karimojong of Uganda. As part of political education, it supports the idea that in the African context, political 'ideologies' have developed out of socio-cultural situations and that politics in Africa has always been intimate and immediate, rather than remote and faceless. Emphasizing participation and resisting alienation of the individual through socio-cultural mechanisms rooted in the communal life and experience. Thus African political behavior finds its vitality in the culturally oriented perception of the lived-world. It also shows that, corresponding to the thematic variation of African societies, the patterns of self-rule were not limited to numerically small groups. In the clamorous and personal democracy of the Ibo in Nigeria , the dispersal of authority was achieved through an individuals right to speak and the unanimity of decision.

In the African world-view, religion was a social fact and, from the cultural point of view , it was a Science of Social Control(109-120) Horton rightly observes that in the African apprehension of reality religious concern aims at discovering and influencing the phenomena of everyday world "by discovering constant principles that underlie the apparent chaos and flux of sensory experience", a theme that engaged the attention of early Greek philosophical reflections. Although rooted in the ancestral custodianship of axiomatic moral values, based on its mandatory and explanatory nature, as for the Karanga, African thought is based on the model making process, concerned with prediction based on observation. It is evident from the Kalabari model of reality, consisting of a triangle of forces, representing the spirits of "founding fathers," the spirits of "lineage segments" and the "free-lance spirits" of the waterpeople, embodying the individualistic and competitive aspirations. The social control mechanism is as well inherent in the "tabos" and "totems" which either threaten or strengthen the structure of social reality. By excluding or promoting certain events, totems and tabos reflect the desire and conviction to reconstruct the social reality.

It is equally true about those rites and rituals which were connected with the endowment of authority and power.

Whenever the emperor of Oyo died in old Yorubaland, appointed officials are said to have cut off his head, cleaned his skull, and taken out his heart. During installation rites, the next emperor was "given a dish containing the heart of his predecessor which he had to eat". A little later he was called on to swallow a potion of corn gruel from his predecessor's skull. These dramatic rites were occasioned by the need 'to open his ears to distinguish truth from falsehood', to give his words compelling powers and to assign to him alone the authority to execute criminals and his enemies at home, and to make war on his enemies abroad. The point lay not in the gruesomeness, but in the mobilizing of chartered power behind the granting of a solemn office, thus guaranteeing legitimacy and imposing accountability on its power exercise. (119) 
Same observation applies to beliefs about Witchcraft and Sorcery, (121-130). Metaphysically grounded and morally interpreted, such beliefs were central to the African social control mechanisms. African culture makes due allowance for Evil but only with reference to man's frailty and failure. African religions have generally supposed only one force capable of acting, depending on the circumstance, either for man's good or his woe. In the African comprehension of reality, the limits of the imagined never exceed the limits of the real. Therefore, for purposes of discussion, the imagined activity may be called witchcraft and the real sorcery. The "witch within the ancestrally sanctioned charter, stands for the subversive norms, the impulse to disorder: in short, for the anti-moral which presupposes the moral". (129) In Zande morality, "it is witchcraft" means" it is bad. The Nupe, in Nigeria, identifies the witch with the person who has set aside social values and denies what the society thinks and desires as good.

The Lugbara in north-western Uganda, judges between Good and Evil in terms of his affinity or distance from family cluster and lineage groupings. "The farther away people live, the worse they become. Near strangers may be witches and sorceres ; far away strangers are altogether horrible". Thus, those who live outside the Lugbara moral universe are "upside down" (130-137) people. The evil man, stranger or Lugbara himself, is a witch.

Beliefs about witchcraft are both explanatory and mandatory. The Hehe of central Tanzania believes that no man should depart too greatly from traditional tribal life and that "no man must be too much in advance of his neighbours, or there is danger that a jealous warlock will kill him by witchcraft". (135) The Chewa of Malawi conceive of those who oppose the conservation of ideal social and moral order as possessed by evil."Nothing, in their philosophy, is without an ultimate cause beyond its immediate cause.(137) Davidson argues that Explanation and Prediction (137-142) are as much present in African culture as in those which have institutionalized science. Temperamentally, the African mind disbelieves in coincidental and explains the accidental with reference to the "inner workings of life". Interruptions in the ideal flow of life are due to breakdown of moral order which has human and therefore controllable explanation. Thus, through particular conjunctions of cause and effect, the system protects itself against predictive failure. It is not therefore surprising that the Tallensi, the Chewa and the Lele do not believe in "natural death". They cannot accept or absorb death into their system without a causal explanation. "The Chewa man who neglected his wife died because he had offended the social norm."

Conflict seeks its own resolution. If resentment is internalized and words are kept in the chest, it opens the gates to the entry of Evil. Therefore, The Danger Within. (143-146) is far more real than the external danger. The Amba does not fear the witches of other villages, he fears the witches of his own village. According to the Lugbara, malevolent magic comes only from within and the Azande expresses the force of Evil in the idiom of witchcraft. Hence the concealed psychological relationship between witchcraft and the socio-moral order.

It means that the beliefs in witchcraft were, after all, Useful Magic (146-150) and that rested on the supremacy of man and his power to control and influence his own fate and destiny. The Africans respected their spirits but saved their deepest admiration for man. Onipa ne asem, it is mankind that matters, says the Akan. The African cultures made spirits the servants of living man. 
Social behavior in Africa has always been empirically diversified and ideologically marked by thematic variations. In such a situation it as not always easy to disentangle objective reality from subjective perception. Structures of social sciences are hard to purify of all ideological connotations. The situation becomes all the more complex when societies and cultures derive their vitality and resilience from imperative morality, enthusiasm and solidarity with the ancestral spirit. Psychology requires resolution of socio-cultural tensions within the ancestrally approved chartered and a reconstruction of generalized sense of their "capacity to externalize, publicly accept, and treat anxiety by open rituals carrying sufficient power of therapeutic relief”. Therein lays the Africans Answer to Anxiety. (150-160)

Arts, devoid of existential meaning degenerate and die out. Thus, in the African perspective, dances and religious rituals, witchcraft and magic, carvings and masks have no meaning or relevance outside the context of life. In the African Cultures, social content and moral connotation is never without existential perspective. In the African cultures, art has always been an expression of and a statement about Africans and their identity. Hence the African notion of Art for Life's Sake. (160-167)

In their rain festivals, dance and music, the Dinka people do not intend to "magic rain out of sky". Rather they affirm their relationship with the "right and the natural". The social content and moral connotation is never missing in the African's conception of Art.

The African cosmology, ontology and the African concept of Being is marked by extreme subtlety, internal coherence and secret wisdom. Davidson gives a philosophical account of The Dynamics of Reality (168-190), conveying the meanings behind its symbols. The cosmogony of the Dogon, which is neither simple nor linear , shows an interpenetration of material and immaterial, of form and content, the immediate and the enduring, all held together dialectically in the fusion of conservation and change.

The Bambara celebrates the symbolism of a "concert of opposites" which lies at the heart of life and growth. The dialectical relationship between Pemba (i. e. the being of things) and Faro (i. e. the shaper and reorganizer of the world) implies both conservation and change, Being and Becoming.

Bambara welfare demands respect for each: for the 'given order' guarded by the ancestors, but also the power of change, dynamic impulse of Pemba-Faro, which advances the affairs of men. (173)

The cosmogony of the Diola of Southern Senegal rests on three primary concepts: (1) participation, i. e., the principle of Being which represents a totality where 'everything belong', (2) the principle of interaction, i. e. Becoming and (3) a philosophical optimism "resulting from a dialectical relationship between Being and Becoming."

The dynamic nature of such a world-view does not permit the use of static categories. It offers a synthetic view of Being-in-Becoming which owes its dynamism to the underlying life-force which, like time, moves on, projecting the past into the future. Things acquire their being in and through becoming; matter takes form in motion.

Accepted as a fact- of life, integrated into one's conception of reality, the idea is bound to have vast social and cultural implications. However, the African approach to reality is not a purely theoretical activity; it is connected to practical use and community relations, embracing total human activity, providing ideological support to socio-moral charters of a 
specific form and content. "Thus, in the Congolese conception of social reality, the individual was not only integrated within his community; but he was also systematically opposed to it in the manner of a 'concert of opposites' which made the stuff of daily life.”(176)

Such a view necessitates full recognition of the "accidental" and the 'ffailure'" have Davidson argues that the African Systems fared well in their persistence and resilience to meet the challenge posed by the "Winds of Change". He cites the Yoruba system as an illustrative example.... Philosophy , theology , politics, social theory, land law, medicine , psychology concatenated in (Yoruba) system so tight that to abstract one item from the whole is to paralyses the structure of the whole. (178)

However, the ideal internal consistencies of African societies were subjected to severe strains by the pressure of population growth. Under the force of circumstance, "kinship continuum" suffered serious disequilibrium. The direct simplicities of everyday life were severely injured. The situation called for effective leadership that could ensure socioeconomic adjustments to new alternatives. Transition from_Elders to Kings (183-189) became inevitable. Institutions of personalized government began to emerge in tropical Africa around the middle of the first millennium A.D. In Kanem-Bornu, the Sayfawa Dynasty , the central kingdom of the Mossi, the great Keita rulers in Mali and the Mwana-mutapa in central Africa constitute illustrious example of the modifications that occured in the Kingship authority pattern of their peoples. Islam brought a strong shaping influence and the Arab conquest of North Africa trading opportunities. in the 17 th and $18^{\text {th }}$ centuries opened new vistas of trading opportunities. Kingship of Ghana emerged and on the east coast, political structures of the Central African Shona appeared. The city-states of the Swahili and of Niger Delta served as trade links with the Eastern and Western Worlds. These factors visibly altered The Nature of Kingship (190-211) The Kings, although no longer considered 'Divine', were still the repositories of the ancestral charters. For the Jukun, the office of the King was no longer identical with the person of the king (202) The Mossi made a distinction between the king's 'body natural' and 'body politic'. They buried the King's 'body natural' but preserved his 'body politic'. The founding traditions of the Zanj, like the Jukun of Nigeria, reflects the revolutionary character of chapter 16 of Magna Carta. It is enshrined as their constitutional right to rebel against the King and to overthrow him, if he ruled cruely.

Long distance Trade and Islam (211-224) accelerated the process of change. Egypt the center of this world-wide trade system was, by way to the coasts of Kufra , linked with the Western Sudan and Lake of Chad region. On the East coast, the first Muslim trading settlement is dated about 800 and in the civilization of Swahili we come across the African variant of Muslim culture. It was gold trade which mattered most. Ghana, Kanem-Bornu, Mali and Songhey channelized trade to the north and on the north-western frontier. Muslim civilization spread in southern and central Spain and southern Morroco held a key position. Caravans passed from Sijilmasa through Kairouan, Tripoli, Tlemsen and Fez to Egypt and the political activities in these cities decided the rise and fall of empires and dynasties in the Magrib. The king of the Niger city Gao and the Kings of Kanem-Bornu embraced Islam. The Burber influence opened the road to Islam in Senegal. Nothing was considered more prestigious than a pilgrimage to Mecca. 
The pilgrims returned with more than prestige. They brought new ideas and fashions from the East. Schools of learning were established. Scholars traveled back and forth. Royal courts acquired clerks and chanceries. The fame of Sudanese Kings spread out across the Muslim land. (218) But pagan beliefs were still mixed with Islamic faith. In Kanem-Bournu,

Even the innovating emperor Musa, who is said to have meditated ending his days in Mecca , applied Muslim policies and customs with tentative hand, performed the rites and ceremonies of Mandinka religion... He was regularly required to preside over traditional courts and settle witchcraft cases. (219)

However, as Islam exercised a deepening influence, equivocations developed, enlarging the conflict between Islam and traditional religions . And the same emperor Musa, with all his caution and care for compromise ... extended the application of Islamic law, placed a Qadi at the side of every provincial governor and the central machinery of the state became even more emphatically Muslim. (219)

Long distance trade also introduced new socio-economic pressures and the unities of ' tribal life' were weakened to the breaking point. Growing interest in accumulation resulted in exploitation of those who lived within 'subsistence economy', raiding for slaves were rampant. Rulers, noteably King IdrisAloma in Bornu and the rulers of Songhay empire, developed churning passion for wealth consuming splandour. In 1450, Abdullahi Burja , the Hausa King of Kano, had twenty one settlements of country folks working for him. His successor, Rumfa, 1465-99, for whom al-Maghili, then teaching in Kano, wrote the Risalat al Muluk, The Obligations of Princes, proved even more ambitious.

Stratifications became more and more stronger, diminishing social equality and social justice and when Uthmandan Fodio called for holy war upon the Hausa Kings in 1840, he was able to strike a social as well as religious note, damning the kings as profligates 'whose purpose is to obtain delights and acquire rank' at the cost of ordinary people.(234) New constitutional reforms become imperative and in the Hausa state of Zaria, administrative notifications in power structures were achieved by counterposing merit to right of birth, resulting in the administrative division of capital city between the Madawaki and the Galadima to ensure efficient administration . The king was elected by the elctor's council consisting of mallams who were debarred from political office. The Madawaki and the three Rukuni, Galadima, Wombai and Dallabu . if all these agreed on the course to be pursued , the King could not resist their advice and in fact the power of the state would be against him if he did. (224)

Long-distance trade produced specialists and thus the division of labour determining the structure of Power, Rank and Privilege (224-234). It is best seen in the Swahili city-states which by the $13^{\text {th }}$ century were strongly Muslim in their tone and temper. The balance of power of Chiefs and Kings shifted towards trade and revenue. Increasing density of population demanded more land necessitating radical adjustments in traditional farming which were bound to affect the ecological balance. Slave trades flourished. Offensive and defensive wars got interlocked, since buying of guns and selling of captives got interlinked. Such pressures added weight to the already deepening crisis of structure, demanding new strengths and new forms of organization. Hard structural changes were required. At this stage The Crisis Deepens . (235-243) In the Sudan , attempts at recovering the sociopolitical unities of the past were made by outstanding leaders, working mainly in the central Muslim tradition, 
such as the western Fulani leader, al-Hajj Umar bin Said, the Eastern Fulani leader Uthmandan Fodio and his far more political son, the Amir-al Muminin Muhammad Bello; the Mahdi of the Eastern Sudan, Muhammad Ahmad ibn Abdullahi, whose conceptions went as far as unity for the whole Sudan; the Almamy Samori Turay in the region of the Niger Senegal and lesser figures such as Ma Ba and Mamadu Lamine. (241)

"Much of Africa was now involved in a process of socioeconomic change and although the ancestral charters were very still as vital as before, the new problems could not be contained in the old frameworks; the old systems were powerless to meet the brusque and rending challenge of industrial production". (243)

Yet the Africans continued to grow and to adjust; even in the cultural suffocation of the 'settler colonies'. However, as it is illustrated by the wars of 1960 against Portuguese rule in Guinea Bissau, Angola and Mozambique, and during the Congo revolts of 1964 the resistance offered by the Africans to the colonial pressure provides cognitive maps that determined various levels of reaction in different directions of thought and action.

A radical shift (not change) in their ideological perspective has already occurred. During these wars, no village African believed that he could turn away the Portuguese bombs or liquify the bullets to water by his spells. The old magic was gone. "Now they had learned that it is better to take good cover and shoot back straight" , comes a statement From a Guerrilla Diary. (247-250)

In The Great Transition (250-256), Davidson discusses the African's perception of their situation in relation to ancestral charters and modern ideologies, at different levels of consciousness and different forms in different regions.

By 1950, African resistance to colonial occupation acquired a nationalistic tone and accent, as in Belgian Congo. To honor their ancestors, the nationalists in Rhodesia named their land Zimbabwe and called their war ChiMurnga, as they had done in their resistance of 1896-7.

Political self-affirmation was reflected in the formation of political parties, and the concept of nationhood. To discourage the African trends toward self-affirmation and nationhood, the colonial powers reduced many hundreds of pre-colonial states to some four dozen colonies and then to four-dozen nations. Yet the process could not be halted. (256-264)

The Kings joined in the procession of revolutionaries and gods; they too resisted and became historical. "He who makes the powder", observed a king of Dohomey, "wins the war". Structural changes in form and content, were reflected in the innovations of Asante ruler and his equally progressive predecessor, OseiKwadow. OseiBonsu imported Muslim functionaries from the north and completely demolished the policy of hereditary membership to the council of 'Kings' men' by appointing people to the offices. In Sudan, after 1840s, alHajj bin Said tried to contain the colonial influence through accommodation "The whites are only traders. Let them bring merchandise in their ships, let them pay me with a good stipend and I will live in peace with them.” But the French, occupied with the thoughts of conquest, scoffed at such a policy. 
Umar's son, Ahmadu, continued with his father's policy. But he also could not contain the imperialist appetite for Colonialism. It is best reflected in his acute psychological observation. "I like the French," he remarked, "but do not trust them while they trust us but do not like us." In 1890, the Voulet and Chanoine campaigns in Sudan unmasked the "cruel, violent, undisciplined and degraded nature of Colonial rule”. (261)

A new awakening to reality was reflected in the writings of al-hajj Umar of KeteKrachi ; a poet and pedagogue. In 1893, in the Twilight of the old Gods, (264-275) the Ndebele (or 'Mat abele') was invaded by troops of British South African Company and in three years virtually the whole area passed into the hands of Rhodes agents. In Mashonaland, the Rhodes agents, who had come seeking gold, turned into farmers demanding more land and labor. Soon the Shona people were reduced to "cowardly and miserable niggers" in their own land. If the chiefs refused to pay the hut tax, "the police boys . . . burnt down all the Kraals they came across until the whole atmosphere was dense with smoke of burning rapoko and other corn and grass, while the white passed the time in a pig-sticking match on foot and horse-back.” (266)

In 1896 the Ndebele rose and the Shona joined in the revolt. The awakening to reality proved harsh. In 1904 the Herero took to arms and the guerrilla leader Jacob Morenga emerged. In 1905-7 the MajiMaji war occurred in Tanganyika. In 1913 the Kenya Luo gave birth to the cult of Mumbo and its followers revived the slogan, coined by the nonconformists in Nyasaland in 1890s, AFRICA FOR THE AFRICANS. Their leader, OnyangoDunde , denounced the Christian religion as “rotten”.(272)

The years passed by and Christian notions and beliefs partly displaced traditional religion and became blended into political framework. The framework acquired a more consciously modern context in language as well as deployment of ideas. The separatist Christian Churches and Christian God became African and with an intensely activist and native mood and temper, the "new churches . . . became, in territory after territory, the fosterparents of the politics of later years". (274-75) However, the political implications of African Christianly could not avoid a rash conflict with the colonial set-up. This constituted the burden of the New Redeemers. (275-288)

In 1921, Pastor Enoch Mgijima's Children of Israel built a settlement in the Ciskei area a forbidden land to them in the apartheid Africa and General Smuts cleaned the area, sending the survivors into prisons and Native Reserves. Readjustments in political thought occurred in the form of an African Christianity. "Ethiopian Movement", symbolized the separatist African Christian reaction, clearly political in content, independent of European Pastors and culture, making a passage from prophets to leaders.

Kenan Kawana of Malawi founded the Watchmen’s Society. "People must not be afraid to break government's laws, "he taught, "nobody should remove his hat to the provincial commissioner or the District Commissioner. These gentlemen . . . are pretenders". (282)

Christian-pagan symbiosis gave rise to ideological synthesis. In a picture and at the request of Simon Kimbangu, a Congolese, Christ was shown as handing over the keys of power to an African political leader. Marcus Garvey, a Jamaican, founded the Universal Negro Improvement Association, established the African Orthodox Church, published the Negro World and proclaimed himself the Provisional President of Africa. Kenya's rebels such as Harvey Thuku, drew their inspiration from prevalent ideas and the European-educated few 
to conceptualize African's problems in non-colonial and then in anti-colonial terms. Out of their teachings, a new resistance emerged, now firmly set in The Modern Context. (259-293) The educated minority, European by adoption, found itself antithetically opposed to the cultures from which it sprang. New respect for native cultures, and stronger echoes of an intellectual revolt against European paternalism were resonant all over the continent. The national Congress of British West Africa was founded in 1920.

But politics still revolved around the intellectuals who, curiously enough, were far removed from the village masses, the workers and the traders. The conservative lawyer politicians were still linked to traditional ruling groups. But , after 1945, SekouToure, with his Rassemblement Democratique, Kwame Nkrumah in Ghana (with his Convention People's Party) and Nnamdi Azikiwe in Nigeria, with their mass political organizations, left the lawyer far behind to lead where the "cautious respectable" did not dare to tread. Their success was linked with the mass movements simmering in the back ground of colonial life, Conversely, the mass movements found their way ahead because they had acquired leaders with an adequate nationalist theory and strategy. At this stage, The Masses React (293-311). The First World War altered the global realities and gave the political consciousness of 1920s and 30s a more practical turn. A protonationalism emerged. Harry Thuku rejected European moral teachings and in 1921 founded a dissident political organization the Young ikuyu Association.

After the Second World War and its grueling enlightenment, Kenya nationalism reached the mass political dimension, urging the masses to fight their way to clarity through familiar categories of thought. Men like Edward Blyden (well known for his concepts of 'African Personality' and 'negritude') George Padmore and Clements Kadalie helped shape the African consciousness in their own ways. External influences, such as the Indian National Congress, landed moral support to the political aspirations of the African National Congress. Anti-racialist and anti-colonialist movements all over the world, revolutionary socialism, legalization of trade-unionism, brought into sharp focus the impending issues of African independence. Nothing, however, aroused the masses more than the factors internal to the colonial process "the sickness of the beast itself". These factors transformed the colonial condition into a major social upheaval and economic disaster, revealing the fatal contradictions inherent in colonialism. But by this time colonialism had eaten deeply into the fabric of ancestral charters disrupting the traditional structures. "Even where this presence reinforced the power of rulers, as in the emirates of Northern Nigeria, it did so at the cost of weakening those checks and balances by which the old Systems had controlled the abuse of power, and so in turn prepared the way for change. (298) The process acquired a dynamic of its own. It was a time of great cultural stress, ideological confusion and profound anxieties.

The growth of primary and secondary education contributed to the process of 'great transition'. Curiously, however, it abruptly turned away from the teachings of the past, creating alienated and dispossessed young people. In the flux of rural emigration, traditional beliefs and patterns of social interdependence were undermined by frantic individualism and the urban values of 'free enterprise'. Old respectabilities and servitudes were thrown away and the gravitas of family life were assaulted by the rootless folks and emancipated women. The city life of Congo Africans could no longer keep a pace with the socio-cultural mechanism. To the afflicted ones, the option was plain and simple: To act for good meant to oppose the agents for evil. In political terms, it meant to act against authority. 
By 1950s, the educated few had mastered the complexities of Westminster and Palais Bourbon and grasped the ideological alternatives more firmly. It was time, they argued, to move from the politics of reforms to the politics of revolution, i.e. the politics of self-rule, the right of the Africans to determine their own destinies. However, the political and social models of these elites were based on the ideology of nation-state, far removed from rural Africa. With the passage of time, these intellectuals, the Wabenzis, lost their bearings and became shallow and rootless symbols of decolonization. Unwittingly, the reformist elites got sucked into the colonial policy, whether English or French, of building an 'indigenous middle-class' , the inheritors of political power. Ironically, the reformers found it sensible to turn their backs on historical Africa, as though this was a world which had passed away, or, if still surviving, one that need no longer much concern them. (309)

Three years after Lumumba's murder, in 1964, Mulele's revolt occurred. In his reliance on Traditional as well as modern ideas, Mulele cut away from the Belgian as well American models. He rejected the 'middle class' reformism and worked out a synthesis of the old and new ideologies, blending the moral and military maxims of Mao Tse-tung into the power that flows from traditional developments. In three years' time, his followers cleared half their countryside of Portuguese army and administration. In Guinea-Bisau, Angola and Mozambique, except for those educated in Lisbon, the masses had already launched their armed revolt. Now the reformist and political elites had to learn what divided or might unify the many ethnic groups in each of these territories. They had to understand at what points the old systems still held firm, and where these systems had degenerated into mere agencies of colonial rule. (312)

Davidson concludes his book by asking a few practical questions in the AFRICAN DESTINIES (313-317) These questions revolve around:

\section{WHAT KIND OF AFRICA MAY NOW EMERGE: WHAT MODERN VARIANT OF AN OLD CIVILIZATION.}

The upheavals of 1960s were not accidental; they reflected a crisis of institutions on a continental scale. Initiated by colonialism, the crisis was deepened by the dismantlement of the colonial period itself, leaving behind nothing but catastrophic cultural and institutional dislocations.

Contrary to the "cheerful school" of colonial historians who have deluded themselves into believing that colonialism ushered a new and constructive era and conducted African into the modern world, Davidson believes that "all that emerged from colonial periods, in a structural sense, was an institutional void concealed for a while behind a political safety curtain painted with parliamentary symbols of European provenance, a mere façade of order on lines drawn by alien cultures”. (314)

Looked at from another standpoint, Africa faces a crisis of growth. By the year 2000 the total population of Africa will have redoubled. This means that productivity in food supply will call for major changes in socio-economic structures and thus in rural attitudes. Unless the rural millions are enthused and energized and thus integrated into structures of politico-economic participation, creative powers of the African people will still remain latent and dormant.

What is needed is a bold vision that will reorient and reconstruct the national awareness of the African people. Borrowed and inherited from Europe, the concept of nation- 
https://ir.iba.edu.pk/businessreview/vol9/iss1/10

DOI: https://doi.org/10.54784/1990-6587.1233

Business Review - Volume 9 Number 1

January - June 2014

states had been in trouble since 1960. "The one great attempt at federation in Nigeria had gone far towards ruin through the rivalry of its constituent elites. Manifestly, federation still held the key: just as clearly it would have to be federation on a structural basis far more popular than elitist rule could apparently provide”. (316)

TUFAIL A.QURESHI

Institute of Business Administration Karachi, Pakistan

“Only that truly exist which can say 'I am'. It is the degree of the intuition I am that determines the place of a thing in the scale of being."

Iqbal 